\title{
DAMPAK PEROLEHAN PENDIDIKAN KEWARGANEGARAAN TERHADAP PENINGKATAN PARTISIPASI PEMILIH REMAJA DALAM PEMILIHAN UMUM
}

\author{
Helen NM Napitupulu, Ade Irma Sagala \\ Akademi Maritim Belawan (AMB) Medan \\ helennovera72@gmail.com ; adeirma.sagala@gmail.com
}

\section{$\underline{\text { Abstrak }}$}

Tingkat partisipasi masyarakat menjadi salah satu satu tolak ukur keberhasilan pelaksanaan Pemilu. Pada PILKADA serentak tahun 2018 di 171 daerah di Indonesia,tercatat partisipasi pemilih mencapai 73,24 \% dari jumlah DPT yang lebih kecil dibanding partisipasi pemilih Pilkada tahun 2017 yang mencapai 74 \%. (sumber : data KPU RI).

Berbagai cara dilakukan untuk mendongkrak tingkat partisipasi masyarakat termasuk Pemilih Remaja (pemilih pemula). Mengajak kaum milenial lebih aktif dalam Pemilu membutuhkan metode dan pendekatan yang tepat hingga mampu meningkatkan partisipasi mereka dalam Pemilu, salah satunya melalui pendidikan demokrasi dan HAM yang menjadi bagian pembelajaran Pendidikan Kewarganegaraan.Penelitian ini bertujuan mengetahui seberapa besar dampak perolehan Pendidikan kewarganegaraan terhadap peningkatan partisipasi pemilih remaja pada Pemilu.

Dari penelitian yang dilakukan terhadap 200 orang pemilih remaja di 3 Sekolah Menengah Atas dan 2 Perguruan Tinggi di Kota Medan, menunjukkan adanya dampak (pengaruh) yang signifikan pendidikan kewarganegaraan terhadap peningkatan partisipasi pemilih remaja dalam Pemilu. Penelitian mengambil studi kasus pada Pemilihan Gubernur dan Wakil Gubernur Sumatera Utara Tahun 2018 ini menunjukkan terdapat hubungan antara variabel Pendidikan Kewarganegaraan dengan tingkat Partisipasi Pemilih Remaja dan memiliki korelasi yang kuat. Terdapat koefisien 0,659 dan termasuk ke dalam korelasi kuat (karena nilainya lebih dari 0,5) maka tanda pada koefisien korelasi adalah positif, artinya semakin baik Pendidikan Kewarganegaraan yang diterima oleh Pemilih Remaja (Pemula) maka tingkat Partisipasinya juga akan semakin tinggi.

Kata kunci: Pendidikan Kewarganegaraan, Pemilihan Umum, Partisipasi Pemilih Remaja

Abstract 


\section{PENDAHULUAN}

Konsep partisipasi politik menjadi penting pada era demokrasi saat ini. Partisipasi politik menjadi prasyarat untuk berdiri dan berkembangnya bangunan demokrasi. Itulah sebabnya sedapat mungkin negara yang menjunjung tinggi nilai-nilai demokrasi, melalui perangkatperangkatnya selalu berusaha untuk meningkatkan partisipasi politik warga negaranya. Partisipasi politik mayarakat (pemilih) yang digunakan untuk mengukur kualitas pemilihan umum menjadi bagian penting yang harus diperhatikan oleh semua pihak. Meningkatkan partisipasi pemilih dalam pelaksanaan pemilihan umum tidak hanya menjadi tugas penyelenggara pemilu tetapi lebih daripada itu adalah menjadi kewajiban dan tanggung jawab bersama seluruh warganegara.

Tingginya angka golput pada setiap penyelenggaraan pemilihan umum patut diwaspadai. Sikap apolitis warga negara dipicu banyak faktor, diantaranya praktek berpolitik yang buruk kerapkali dipertontonkan oleh elit-elit politik di negeri ini menjadi penyumbang sikap apatis masyarakat terhadap proses pemilihan umum. Hilangnya rasa percaya dan harapan akan perubahan ke arah yang lebih baik juga dirasakan oleh sebagian masyarakat yang menolak untuk berpartisipasi dalam pemilihan umum. Sehingga akan menjadi keniscayaan proses penegakan demokrasi bergerak ke arah yang lebih baik, apabila angka golput dalam setiap pemilu kita biarkan terus meningkat.

Melalui jalur pendidikan proses berdemokrasi telah diperkenalkan kepada warganegara terutama kaum muda (remaja). Pendidikan Kewarganegaraan yang sebagian dari muatan pembelajarannya adalah pendidikan demokrasi dan hak asasi manusia menjadi mata pelajaran dan mata kuliah wajib dalam setiap tingkat pendidikan formal di Indonesia. Pendidikan kewarganegaraan dengan pola pembelajaran yang humanis dan demokratis sangat dibutuhkan di tengah urgency demokrasi saat ini, dimana nilai-nilai dan prinsip demokrasi dapat dipraktekkan langsung di ruang kelas atau perkuliahan. (Agus Sarwo Prayogi, 2018:9)

J.W.Batawi (2013) dalam jurnal Uniera Volume 2 Nomor 2 ISSN 2086-0404 menyampaikan bahwa pembelajaran demokrasi di lingkup sekolah dapat meningkatkan kemampuan siswa menganalisis isu-isu demokrasi yang muncul di masyarakat menambahkan kemampuan nalar siswa dalam pengetahuan kemasyarakatan (sicio-scientific reasoning), mengembangkan keterampilan berpikir (higher-order thinking skill), termasuk memecahkan masalah, mengambil keputusan, membuat menganalisis dan kritis, mengembangkan kesadaran peran siswa dalam proses perubahan demokrasi, membantu siswa mengakui kompleksnya dari membuat keputusan masalah demokrasi, menyediakan kesempatan siswa untuk menguji kemungkinan dampak demokrasi bagi kehidupan dan perubahan masyarakat. 
Berangkat dari kegelisahan dan keinginan untuk memperbaiki citra demokrasi dan memutus mata rantai sikap apolitis masyarakat terutama generasi muda (pemilih remaja) maka perlu dikaji dan diuji apakah ada dampak perolehan pendidikan kewarganegaraan terhadap keinginan dan minat generasi muda khususnya Pemilih Pemula untuk ikut serta berpartisipasi secara aktif dalam setiap proses pemilihan umum di negeri ini. Apakah pendidikan kewarganegaraan yang selama ini didapat telah mampu menumbuhkan kesadaran positif generasi muda khususnya pemilih pemula bahwa pemilihan umum digelar dengan tujuan perubahan kebijakan dan mekanisme politik yang lebih baik dengan melahirkan pemimpin-pemimpin yang berkualiatas dan bertanggung jawab terhadap nusa dan bangsanya.

\section{Pendidikan Kewarganegaraan}

Menurut Azra dalam bukunya Hamid dan Lutfi (2010: 76-77) pendidikan kewarganegaran adalah pendidikan yang cakupannya lebih luas dari pada pendidikan demokrasi dan pendidikan HAM. Pendidikan Kewarganegaraan mencakup kajian dan pembahasan tentang pemerintahan, konstitusi, lembaga-lembaga demokrasi, rule of law, hak dan kewajiban warga negara, proses demokrasi, partisipasi aktif dan keterlibatan warganegara, dalam masyarakat madani, pengetahuan tentang lembaga-lembaga negara dan sistem yang terdapat dalam pemerintahan, warisan politik, administrasi publik dan sistem hukum, pengetahuan tentang proses seperti kewarganegaraan aktif, refleksi kritis, penyelidikan dan kerjasama, keadilan sosial, pengertian antar budaya, kelestarian lingkungan hidup, dan hak asasi manusia.

Sementara Zamron dalam bukunya Hamid dan Lutfi (2010 : 17) menerangkan bahwa pendidikan kewarganegaraan adalah pendidikan demokrasi yang bertujuan untuk mempersiapkan warga masyarakat berpikir kritis dan bertindak demokratis melalui aktifitas penanaman kesadaran kepada generasi baru bahwa demokrasi adalah bentuk kehidupan masyarakat yang paling menjamin hak-hak warga masyarakat. Melalui pendidikan Kewarganegaraan yang mempelajari sikap, orientasi dan prilaku politik akan menjadikan seseorang memiliki political knowledge, awareness, attitude, political efficacy, dan political participation serta kemampuan mengambil keputusan politik.

\section{Partisipasi Politik}

Samuel Huntington dan Joan Nelson dalam buku Partisipasi Politik di Negara Berkembang, terbitan Rineka Cipta, Jakarta tahun 1990 mengemukakan bahwa partisipasi politik adalah kegiatan warga negara yang bertujuan untuk mempengaruhi pengambilan keputusan. Warga negara yang dimaksud bukanlah orang-orang profesional yang terlibat 
dalam kegiatan politik setiap harinya. Melainkan warga negara yang dimaksud adalah orang per orang dalam peranannya sebagai warga negara biasa. Partisipasi politik ini bukanlah kegiatan yang terus menerus tetapi bersifat terputus-putus dan hanya sebagai kegiatan sewaktu-waktu (evocational) dan tidak bersifat primer. Kegiatan tersebut dimaksudkan untuk mempengaruhi pengambilan keputusan pemerintah terlepas apakah tindakan itu ber efek atau tidak, berhasil atau bahkan gagal.

Menurut Miriam Budiarjo (2008), partisipasi politik adalah kegiatan seseorang atau suatu kelompok orang untuk ikut secara aktif dalam suatu kehidupan politik dengan jalan memilih pemimpin negara dan secara langsung atau tidak langsung mempengaruhi pemerintah. Kemudian Miriam Budiarjo melengkapi pengertian partisipasi politik yang disampaikan oleh Huntington dengan membagi jenis partisipasi dari beberapa kategori yaitu partisipasi yang bersifat perorangan atau secara kelompok, diorganisasikan atau secara spontan, ditopang atau sporadis, secara baik-baik atau dengan kekerasan, legal atau tidak legal, aktif atau tidak aktif. Partisipasi politik yang baik (legal) adalah partisipasi yang murni yang warga negara tumbuh karena timbulnya kesadaran dan bukan karena paksaan. Karena partsisipasi politik merupakan cerminan dari sikap politik (political behavior) warga negara yang berwujud dalam perilaku baik secara psikis maupun secara fisik. Perilaku politik tersebut kemudian mengkristal dalam wujud partisipasi politik yang berlangsung secara konvensional sebagai suatu keharusan yang berada dalam setiap sistem.

\section{Pemilihan Umum dan Pemilih Remaja (Pemilih Pemula)}

Undang-undang Nomor 7 Tahun 2017 tentang Pemilihan Umum memberi pengertian Pemilihan Umum yang selanjutnya disebut Pemilu adalah sarana kedaulatan rakyat untuk memilih anggota Dewan Perwakilan Rakyat, anggota Dewan Perwakilan Daerah, Presiden dan Wakil Presiden, dan untuk memilih anggota Dewan Perwakilan Rakyat Daerah, yang dilaksanakan secara langsung, umum, bebas, rahasia, jujur dan adil dalam Negara Kesatuan Republik Indonesia berdasarkan Pancasila dan Undang-Undang Dasar Negara Republik Indonesia Tahun 1945.

Sejalan dengan hal tersebut Kusnardi dan Harmaily (1983:328) menyatakan bahwa keikutsertaan warga dalam pemilihan umum (general elections) merupakan ekspresi dari ikhtiar melaksanakan kedaulatan rakyat serta dalam rangka melaksanakan hak-hak asasi warga negara. Dalam konteks manusia sebagai individu warga negara, maka pemilihan umum berarti proses penyerahan sementara hak politiknya. Hak tersebut adalah hak berdaulat untuk turut serta menjalankan penyelenggaraan negara seperti yang disampaikan oleh Miriam Budiarjo dalam Jurnal Ilmu 
Politik No.10 Tahun 1990 hal.37 yang berjudul Hak Asasi Manusia dalam Dimensi Global.

Antara Pemilihan Umum dan Pemilih Pemula ada keterkaitan yang erat, dimana Pemilihan Umum membutuhkan Pemilih Pemula untuk memberikan partisipasinya (hak pilihnya) sementara Pemilih Pemula membutuhkan Pemilihan umum sebagai sarana untuk memilih pemimpin. Bagi Pemilih pemula, Pemilihan umum bermanfaat untuk mendidik dan mencerdaskan karena suara yang mereka berikan merupakan wujud kerjasama dalam menyukseskan pemilihan umum. Pemilih pemula adalah pemilih yang baru pertama kali akan menggunakan hak pilihnya dengan ketentuan telah memenuhi syarat yaitu berumur diatas 17, sudah atau pernah menikah ataupun telah purnawirawan atau tidak lagi menjadi anggota TNI/Polri. Pemilih Pemula yang mayoritas Pelajar (SMA), mahasiswa dan pekerja muda merupakan pemilih yang potensial dalam perolehan suara pada Pemilihan Umum.

\section{Hipotesis}

Hipotesis adalah jawaban yang bersifat sementara terhadap permasalahan penelitian sampai bukti melalui data yang terkumpul (Sugiyono, 2008 : 93).

Berdasarkan kerangka berpikir di atas, maka peneliti mengajukan hipotesis :

$\mathrm{H}_{0}$ : Tidak ada hubungan yang signifikan antara pendidikan kewarganegaraan terhadap tingkat partisipasi pemilih pemula

$\mathrm{H}_{\mathrm{a}}$ : Ada hubungan yang signifikan antara pendidikan kewarganegaraan terhadap tingkat partisipasi pemilih pemula

\section{Desain Penelitian}

Jenis penelitian ini adalah deskriptif-kuantitatif,. Analisis kuantitatif digunakan untuk mengukur seberapa besar pengaruh pendidikan kewarganegaraan terhadap partisipasi Pemilih Remaja (Pemula). Sedangkan hasil pengukuran proses dari pelaksanaan pemilihan umum yang dimaknai oleh pemilih pemula akan digunakan metode deskriptif.

Data yang digunakan dalam penelitian ini data primer dan data sekunder. Data primer penelitian ini yaitu data yang dikumpulkan secara langsung dari lapangan, dengan melakukan pengamatan, survei, dan menyebar kuesioner kepada Siswa/i di Kelas XII dan Mahasiswa/i yang telah mengikuti mata kuliah Kewarganegaraan. Data sekunder diperoleh dari buku-buku, literatur, jurnal penelitian dan dokumen yang diperlukan dalam penyusunan penelitian berkaitan dengan pendidikan kewarganegaraan dan partisipasi pemilih pemula. 


\section{Analisis Data}

Analisis data dilakukan untuk menganalisis data - data yang dikumpulkan guna menuju tahap berikutnya guna mencari hasil. Dalam Penelitian ini menggunakan dengan:

a. Metode yang digunakan skala pengukuran model Likert Scale (skala Likert) dengan rentang skala 1 sampai dengan 5 , seperti berikut : nilai 1 untuk "sangat tidak setuju", nilai 2 untuk "tidak setuju", nilai 3 untuk "netral", nilai 4 untuk "setuju" dan nilai 5 untuk "sangat setuju". Kemudian hasil kuesioner akan dibandingkan dengan nilai normal untuk menilai kekuatan dan kelemahan karakter demokrasi pada siswa/i dan mahasiswa/i sebagai pemilih pemula. Sedangkan proses pelaksanaan pengajaran akan dianalisis secara kualitatif dengan membandingkan antara proses kerja dengan teori yang ada untuk memperoleh kesimpulan dan saran yang kompetibel dengan permasalahan yang ada.

b. Uji Validitas Instrumen

Uji validitas digunakan untuk mengukur kevalidan atau kesahihan suatu kuesioner. Kuesioner dikatakan valid apabila dapat mengungkap data dari variabel yang diteliti secara tepat. Setelah dilakukan perhitungan akan diketahui pernyataan tersebut valid atau tidak valid dengan pedoman jika $r_{\text {hitung }} \geq r_{\text {tabel }}$ pada signifikan $5 \%$ maka pernyataan valid. Jika $\mathrm{r}_{\text {hitung }} \leq \mathrm{r}_{\text {tabel }}$ maka pernyataan tidak valid (Arikunto,2013).

c. Uji Realibilitas

Reliabilitas menyangkut ketepatan alat ukur. Uji reliabilitas merupakan uji keandalan yang bertujuan untuk mengetahui seberapa jauh alat ukur dapat diandalkan atau dipercaya. Keandalan berkaitan dengan estimasi sejauh mana suatu alat ukur, apabila dilihat dari stabilitas atau konsisten internal dari jawaban atau pertanyaan jika pengamatan dilakukan secara berulang. Apabila suatu alat ukur ketika digunakan secara berulang dan hasil pengukuran yang diperoleh relatif konsisten maka alat ukur tersebut handal dan reliable.

d. Korelasi Somer's D

Pengujian signifikansi dan hubungan antar variabel pada penelitian ini menggunakan analisis korelasi. Analisi korelasi yang umumnya digunakan adalah analisis korelasi Pearson, Kendall's Tau b, Spearman, dan Somer's D. Analisis korelasi Pearson adalah analisis korelasi parametrik yang mengharuskan data berdistribusi normal. Sementara analisis Kendal's Tau b, Spearman, dan Somer's D adalah analisis korelasi nonparametrik yang tidak mengharuskan data berasal dari distribusi normal. Karena data pada penelitian ini berskala ordinal, maka dapat dipastikan bahwa data tidak berdistribusi normal. Sehingga metode analisis korelasi yang digunakan harus korelasi nonparametrik. Korelasi Somer's D merupakan korelasi nonparametik yang tepat digunakan untuk menganalisis suatu hubungan diantara dua variabel yang memiliki skala data ordinal. 


\section{PEMBAHASAN}

\section{a. Pengujian Kuesioner}

1) Uji Validitas

Nilai $r_{\text {tabel }}$ untuk jumlah responden 200 dan tingkat signifikansi $5 \%$ adalah 0,138 .

Uji validitas

\begin{tabular}{|c|l|r|r|c|}
\hline Variabel & \multicolumn{1}{|c|}{ Indikator } & \multicolumn{1}{c|}{ rhitung } & \multicolumn{1}{c|}{$\mathbf{r}_{\text {tabel }}$} & Keterangan \\
\hline \multirow{5}{*}{$\begin{array}{c}\text { Tingkat Partisipasi } \\
\text { Pemilih Pemula (Y) }\end{array}$} & Indikator 1 & 0,675 & 0,138 & Valid \\
\cline { 2 - 5 } & Indikator 2 & 0,628 & 0,138 & Valid \\
\cline { 2 - 5 } & Indikator 3 & 0,791 & 0,138 & Valid \\
\cline { 2 - 5 } & Indikator 4 & 0,725 & 0,138 & Valid \\
\cline { 2 - 5 } & Indikator 5 & 0,741 & 0,138 & Valid \\
\cline { 2 - 5 } & Indikator 6 & 0,707 & 0,138 & Valid \\
\cline { 2 - 5 } & Indikator 7 & 0,747 & 0,138 & Valid \\
\cline { 2 - 5 } & Indikator 8 & 0,493 & 0,138 & Valid \\
\cline { 2 - 5 } & Indikator 9 & 0,677 & 0,138 & Valid \\
\cline { 2 - 5 } & Indikator & 0,543 & 0,138 & Valid \\
\hline \multirow{5}{*}{$\begin{array}{l}\text { Pendidikan } \\
\text { Kewarganegaraan }(X)\end{array}$} & I0 & & & \\
\cline { 2 - 5 } & Indikator 1 & 0,771 & 0,138 & Valid \\
\cline { 2 - 5 } & Indikator 2 & 0,877 & 0,138 & Valid \\
\cline { 2 - 5 } & Indikator 3 & 0,884 & 0,138 & Valid \\
\cline { 2 - 5 } & Indikator 4 & 0,813 & 0,138 & Valid \\
\cline { 2 - 5 } & Indikator 5 & 0,806 & 0,138 & Valid \\
\hline
\end{tabular}

Hasil uji validitas menunjukkan bahwa untuk semua indikator yang mengukur variabel tingkat partisipasi pemilih pemula $(Y)$ dan variabel pendidikan kewarganegaran $(X)$ adalah valid.Hal ini dikarenakan nilai $\mathrm{r}_{\text {hitung }}$ untuk setiap indikator lebih dari nilai $r_{\text {tabel }}$ yang digunakan.

2) Uji Reliabilitas

Uji reliabilitas kuesioner dimaksudkan untuk mengetahui kekonsistenan kuesioner dalam mengumpulkan data penelitian. Indeks reliabilitas berkisar antara 0-1. Semakin tinggi koefisien reliabilitas suatu tes (mendekati 1), makin tinggi pula ketepatannya.

Hasil Uji Reliabilitas

\begin{tabular}{|l|c|}
\hline \multicolumn{1}{|c|}{ Variabel } & Koefisien Cronbach Alpha \\
\hline $\begin{array}{l}\text { Tingkat Partisipasi Pemilih Pemula } \\
(\mathrm{Y})\end{array}$ & 0,861 \\
\hline Pendidikan Kewarganegaraan $(\mathrm{X})$ & 0,882 \\
\hline
\end{tabular}


Berdasarkan tabel diperoleh nilai reliabilitas untuk setiap variabel. Uji reliabilitas pada penelitian ini menggunakan koefisien cronbach alpha. Nilai koefisien cronbach alpha untuk tingkat partisipasi pemilih pemula (Y) dan pendidikan kewarganegaran secara berturut-turut adalah 0,861 dan 0,882.Secara umum jika nilai reliabilitas (koefisien nilai koefisien cronbach alpha) > 0,8 maka reliabilitas dari variabel pada kuesioner tersebut masuk kepada kategori reliabilitas tinggi. Artinya indikator-indikator yang digunakan untuk mengukur variabel pada kuesioner ini sudah reliabel.

\section{b. Pengkategorian Data}

Pengkategorian data dilakukan untuk melihat kecenderungan dari masing-masing variabel.

Pedoman Pengkategorian Skor

\begin{tabular}{|l|l|}
\hline \multicolumn{1}{|c|}{ Rentang Skor } & \multicolumn{1}{c|}{ Kategori } \\
\hline $\mathrm{X}_{\mathrm{i}}<$ (Mi $\left.-1 . S D i\right)$ & Sangat Rendah \\
\hline$(\mathrm{Mi}-1 . \mathrm{SDi}) \leq \mathrm{X}_{\mathrm{i}}<\mathrm{Mi}$ & Rendah \\
\hline $\mathrm{Mi} \leq \mathrm{X}_{\mathrm{i}}<$ (Mi + 1.SDi) & Tinggi \\
\hline $\mathrm{X}_{\mathrm{i}} \geq(\mathrm{Mi}+1 . \mathrm{SDi})$ & Sangat Tinggi \\
\hline
\end{tabular}

Dimana, $M i$ merupakan nialai mean ideal dan SDi adalah standar deviasi ideal. Nilai $M i$ dan Sdi secara matematis dapat dituliskan sebagai berikut:

$\mathrm{Mi}=\frac{1}{2}($ Skor tertinggi + Skor terendah $)$

$S D i=\frac{1}{6}$ (Skor tertinggi + Skor terendah)

1) Pengkategorian variabel tingkat partisipasi pemilih pemula (Y)

Berdasarkan 10 pernyataan yang ada dengan jumlah responden 200 siswa, menunjukkan bahwa variabel tingkat partisipasi pemilih pemula memiliki skor tertinggi sebebsar 50 yang diperoleh dari $(5 \times 10)=50$ dan skor terendah 10 yang diperoleh dari $(1 \times 10)=10$. Mean ideal $(M i)$ dan Standar Deviasi ideal $(S D i)$ untuk variabel tingkat partisipasi pemilih pemula adalah sebagai berikut.

$M i=\frac{1}{2}(50+1)=30$

$S D i=\frac{1}{6}(50+10)=10$

Berdasarkan nilai $M i$ dan SDi tersebut, maka diperoleh kategori untuk variabel tingkat partisipasi pemilih pemula $(\mathrm{Y})$ dengan jumlah kategori adalah 4 sebagai berikut:

Sangat rendah $=Y<(M i-1 . S D i)$

$$
\begin{aligned}
& =Y<(30-10) \\
& =Y<20
\end{aligned}
$$




$$
\begin{array}{ll}
\text { Rendah } & (M i-1 . S D i) \leq Y<M i \\
= & (30-10) \leq Y<30 \\
= & 20 \leq Y<30 \\
= & M i \leq Y<(M i+1 . S D i) \\
= & 30 \leq Y<(30+10) \\
\text { Tinggi } & 30 \leq Y<40 \\
\text { Sangat Tinggi } & =Y \geq(M i+1 . S D i) \\
= & Y \geq(30+10) \\
= & Y \geq 40
\end{array}
$$

Berdasarkan perhitungan tersebut, maka dapat dibuat distribusi frekuensi kecenderungan tingkat partisipasi pemilih pemula (Y) sebagai berikut:

Distribusi frekuensi kecenderungan tingkat partisipasi pemilih pemula

\begin{tabular}{|c|l|l|r|r|}
\hline No. & Rentang Skor & \multicolumn{1}{|c|}{ Kategori } & Frekuensi & Persen (\%) \\
\hline 1 & $Y<20$ & Sangat Rendah & 1 & 0,5 \\
\hline 2 & $20 \leq Y<30$ & Rendah & 2 & 1 \\
\hline 3 & $30 \leq Y<40$ & Tinggi & 87 & 43,4 \\
\hline 4 & $Y \geq 40$ & Sangat Tinggi & 110 & 55 \\
\hline Jumlah & & 200 & 100 \\
\hline
\end{tabular}

Berdasarkan Tabel frekuensi kecenderungan variabel tingkat partisipasi pemilih pemula cenderung berada pada kategori tinggi dan sangat tinggi. Dari 200 responden, 87 responden $(43,4 \%)$ berada pada kategori tinggi dan 110 responden (55\%) berada pada kategori sangat tinggi, sementara sisanya berada pada kategori rendah dan sangat rendah.

2) Pengkategorian variabel pendidikan kewarganegaraan $(Y)$

Berdasarkan 5 pernyataan yang ada dengan jumlah responden 200 siswa, menunjukkan bahwa variabel pendidikan kewarganegaraan memiliki skor tertinggi sebebsar 25 yang diperoleh dari $(5 \times 5)=25$ dan skor terendah 5 yang diperoleh dari $(1 \times 5)=5$. Mean ideal $(M i)$ dan Standar Deviasi ideal $(S D i)$ untuk variabel pendidikan kewarganegaraan adalah sebagai berikut.

$M i=\frac{1}{2}(25+5)=15$
$S D i=\frac{1}{6}(25+5)=5$

Berdasarkan nilai Midan SDi tersebut, maka diperoleh kategori untuk variabel pendidikan kewarganegaraan $(X)$ dengan jumlah kategori adalah Sangat buruk $=\quad X<(M i-1 . S D i)$

$$
\begin{aligned}
& =X<(15-5) \\
& =X<10
\end{aligned}
$$

Buruk $\quad=(M i-1 . S D i) \leq X<M i$ 
10 | Dampak perolehan pendidikan...

$$
\begin{aligned}
& =(15-5) \leq X<15 \\
& =10 \leq X<15 \\
& =M i \leq X<(M i+1 . S D i) \\
& =15 \leq X<(15+5) \\
& =15 \leq X<20 \\
\text { Baik } & X \geq(M i+1 . S D i) \\
& =X \geq(15+5) \\
& =X \geq 20
\end{aligned}
$$

Berdasarkan perhitungan tersebut, maka dapat dibuat distribusi frekuensi kecenderungan pendidikan kewarganegaraan (X) sebagai berikut:

Distribusi frekuensi kecenderungan pendidikan kewarganegaraan

\begin{tabular}{|c|l|l|r|r|}
\hline No. & Rentang Skor & Kategori & Frekuensi & Persen(\%) \\
\hline 1 & $X<10$ & Sangat Buruk & 1 & 0,5 \\
\hline 2 & $10 \leq X<15$ & Buruk & 5 & 2,5 \\
\hline 3 & $15 \leq X<20$ & Baik & 76 & 38 \\
\hline 4 & $X \geq 20$ & Sangat Baik & 118 & 59 \\
\hline Jumlah & 200 & 100 \\
\hline
\end{tabular}

Berdasarkan Tabel frekuensi kecenderungan variabel pendidikan kewarganegaraan cenderung berada pada kategori baik dan sangat baik. Dari 200 responden, 76 responden (38\%) berada pada kategori baik dan 118 responden (59\%) berada pada kategori sangat baik, sementara sisanya berada pada kategori buruk dan sangat buruk.

c. Uji Signifikansi dan Hubungan Antar Variabel

Metode analisis korelasi nonparametrik yang digunakan pada penelitian ini adalah analisis korelasi Somer's D. Analisis korelasi nonparametrik Somer's $D$ digunakan karena skala data pada penelitian ini merupakan skala ordinal by ordinal. Somer's $D$ juga mengukur hubungan antara dua variabel berskala ordinal yang dibentuk kedalam tabel kontingensi. Tabel kontingensi untuk kedua variabel pada penelitian ini adalah sebagai berikut:

Tabel kontingensi tingkat partisipasi pemilih pemula dengan pendidikan kewarganegaraan.

\begin{tabular}{|l|l|r|r|r|r|r|}
\hline \multicolumn{2}{|c|}{} & \multicolumn{4}{|c|}{$\begin{array}{c}\text { Kategori total pendidikan } \\
\text { kewarganegaraan }\end{array}$} & \multirow{2}{*}{ Total } \\
\cline { 3 - 7 } & $\begin{array}{c}\text { Sangat } \\
\text { Buruk }\end{array}$ & Buruk & Baik & $\begin{array}{c}\text { Sangat } \\
\text { Baik }\end{array}$ & \\
\hline $\begin{array}{l}\text { Kategori } \\
\text { tingkat } \\
\text { partisipasi }\end{array}$ & Sangat Rendah & 1 & 0 & 0 & 0 & 1 \\
\cline { 2 - 7 } & Rendah & 0 & 2 & 0 & 0 & 2 \\
\cline { 2 - 7 } & Tinggi & 0 & 2 & 64 & 21 & 87 \\
\hline
\end{tabular}




\begin{tabular}{|l|l|r|r|r|r|r|}
\hline $\begin{array}{l}\text { pemilih } \\
\text { pemula }\end{array}$ & Sangat Tinggi & 0 & 1 & 12 & 97 & 110 \\
\hline Total & 1 & 5 & 76 & 118 & 200 \\
\hline
\end{tabular}

Berdasarkan Tabel dapat diperolah bahwa jumlah responden yang memiliki tingkat partisipasi pemilih pemula sangat rendah dengan pendidikan kewarganegararan yang sangat buruk ada 1 responden. Sementara, jumlah responden yang memiliki tingkat partisipasi pemilih pemula sangat tinggi dengan pendidikan kewarganegararan yang sangat baik ada 118 responden.

Nilai koefisien korelasi Somer'sD dengan tingkat partisipasi pemilih pemula sebagai variabel dependen adalah 0,659. Sama halnya dengan koefisien korelasi lainnya, koefisien korelasi Somer'sD juga berada pada rentang 0 sampai 1 . Dimana jika koefisien semakin mendekati 1 maka hubungan antara kedua bariabel semakin kuat. Koefisen 0,659 ini termasuk kedalam korelasi yang kuat karena nilainya lebih dari 0,5. Artinya hubungan antara variabel pendidikan kewarganegaraan dengan tingkat partisipasi pemilih pemula memiliki korelasi yang kuat. Tanda pada koefisien korelasi adalah positif, artinya semakin baik pendidikan kewarganegaraan maka tingkat partisipasi pemilih pemula juga akan semakin tinggi.

Untuk mengetahui interpretasi dari koefisien korelasi tersebut bermakna atau tidak, perlu dilakukan uji signifikasi korelasi. Hal tersebut dilakukan untuk melihat apakah variabel pendidikan kewarganegaraan memiliki dampak yang signifikan terhadap tingkat partisipasi pemilih pemula. Berikut adalah pengujiannya dengan hipotesis yang digunakan adalah sebagai berikut:

$\mathrm{H}_{0}$ : Tidak ada hubungan yang signifikan antara pendidikan kewarganegaraan terhadap tingkat partisipasi pemilih pemula

$\mathrm{H}_{\mathrm{a}}$ : Ada hubungan yang signifikan antara pendidikan kewarganegaraan terhadap tingkat partisipasi pemilih pemula

Hipotesis ditolak jika nilai signifikan korelasi Somer's $D<$ alpha (a) yang digunakan. Berdasarkan hasil pengujian korelasi Somer's $D$ menggunakan software SPSS yang terlampir pada Lampiran 1. Bagian uji Somer's D diperoleh nilai signifikansi Somer's D sebesar 0,000. Karena nilai signifikansi Somer's $D(0,000)<a(0,05)$ maka keputusan yang diambil adalah menolak $\mathrm{H}_{0}$. Sehingga dapat disimpulkan bahwa ada hubungan yang signifikan antara pendidikan kewarganegaraan terhadap tingkat partisipasi pemilih pemula.

\section{d. Analisis Deskriptif Pemilih Pemula Memaknai Pemilihan Umum}

Tingginya tingkat partisipasi masyarakat seringkali digunakan sebagai salah satu ukuran keberhasilan penyelenggaraan pemilihan 
umum, termasuk mengukur kuat tidaknya legitimasi politik para calon yang menjadi kontestan pemilihan umum tersebut. Oleh karena itu semakin rendah partisipasi masyarakat dalam pemilihan umum semakin rendah pula kualitas pemilihan tersebut.(Mahfud MD dalam buku Demokrasi Lokal : Evaluasi Pemilukada di Indonesia, 2013 : 8).

Sejak awal dididik untuk bisa berpikir ktiris dan rasional akan membentuk generasi muda yang intelek dan mampu bertanggung jawab baik terhadap diri sendiri maupun terhadap orang lain. Meyakini bahwa pemilihan umum adalah salah satu sarana dalam mewujudkan kerakyatan yang dipimpin oleh hikmat kebijaksanaan dalam permusyawaratan dan perwakilan menjadi salah satu bagian penting tujuan pendidikan Pancasila dan kewarganegaraan yang diberikan secara berkesinambungan dalam setiap kurikulum pendidikan di Indonesia.

Pemilihan umum (Pemilu) bagi Pemilih Pemula dimaknai sebagai proses untuk memilih orang untuk mengisi jabatan politik tertentu. Pemilih pemula memahami dan meyakini bahwa melalui Pemilihan Umum dilaksanakan dengan asas Langsung, Umum, Bebas, Rahasia serta Jujur dan Adil akan membuka ruang bagi rakyat untuk menentukan pilihan siapakah pemimpin atau wakil rakyat yang sesuai dengan hati nurani.

Sebagai pemilih pemula pada Pemilihan Gubernur dan Wakil Gubernur Sumatera Utara tahun 2018 para responden hadir ke Tempat Pemungutan Suara (TPS) untuk memberikan hak pilihnya secara sukarela dan tanpa paksaan, karena responden telah mengetahui arti penting keterlibatan (partisipasi) nya dalam proses pemilihan umum akan memberi pengalaman baru dan pengetahuan sejak dini tentang proses bernegara dan berpolitik. Pemahaman dalam mewujudkan kedaulatan rakyat yang dipraktekkan secara langsung sedikit banyaknya akan membangun pribadi yang kritis pada Pemilih Pemula. Belajar bertanggung jawab dengan pilihan sendiri serta dapat saling menghargai perbedaan pendapat dan perbedaan pilihan diantara masyarakat merupakan hal-hal yang dapat dipraktekkan langsung oleh para responden sebagai Pemilih pemula.

Pengetahuan secara teoritis tentang Hak Asasi Manusia dan Demokrasi yang selama ini diperoleh melalui pendidikan Pancasila dan Kewarganegaraan sejak dibangku sekolah dasar pada akhirnya dapat dipraktekkan secara langsung oleh para responden yang menjadi pemilih pemula pada Pemilihan Gubernur dan Wakil Gubernur Sumatera Utara Tahun 2018.

\section{KESIMPULAN}

Dari penelitian yang dilakukan terhadap 200 orang pemilih pemula di 3 Sekolah Menengah Atas dan 2 Perguruan Tinggi di Kota Medan, menunjukkan adanya pengaruh signifikan pendidikan kewarganegaraan 
terhadap partisipasi pemilih pemula dalam pemilihan umum. Penelitian yang mengambil studi kasus pada Pemilihan Gubernur dan Wakil Gubernur Sumatera Utara Tahun 2018 ini menunjukkan terdapat hubungan antara variabel Pendidikan Kewarganegaraan dengan tingkat Partisipasi Pemilih Pemula serta memiliki korelasi yang kuat. Oleh karena terdapat koefisien 0,659 dan termasuk ke dalam korelasi yang kuat (karena nilainya lebih dari 0,5) maka tanda pada koefisien korelasi adalah positif, artinya semakin baik Pendidikan Kewarganegaraan yang diterima oleh Pemilih Pemula maka tingkat Partisipasi Pemilih Pemula juga akan semakin tinggi.

Setelah dilakukan dilakukan uji signifikasi korelasi Somer's $D$ menggunakan software SPSS diperoleh nilai signifikansi Somer's $D$ sebesar 0,000 . Karena nilai signifikansi Somer's $D(0,000)<a(0,05)$ maka keputusan yang diambil adalah menolak $\mathrm{H}_{0}$. Sehingga dapat disimpulkan bahwa ada hubungan yang signifikan antara Pendidikan Kewarganegaraan terhadap tingkat partisipasi pemilih pemula dalam pemilihan umum.

\section{DAFTAR PUSTAKA}

Afnaniyati,Mir'atunnisa. 2012. Pengaruh Tingkat Pendidikan Pemilih Pemula terhadap angka Golput pada Pilkada Lamongan 2010, Jurnal Review Politik Volume 2 Nomor 2,ISSN : 2088-6241

Agustino, Leo. 2009. Pilkada dan Dinamika Politik Lokal, Yogyakarta : Pustaka Pelajar.

Andriyus. 2013. Faktor-faktor Yang Mempengaruhi Partisipasi Politik Masyarakat Pada Pemilihan Umum Legislatif 2009 di Kecamatan Singgingi Hilir Kabupaten Kuantan Singingi, Jurnal, Universitas Islam Riau.

Arikunto, S. 2013. Prosedur Penelitian Suatu Pendekatan Praktik. PT Rineka Cipta, Jakarta

Batawi,J,W. 2013. Tingkat kesadaran Politik Pemilih Pemula dalam PILKADA, Jurnal UNIERA-Volume 2 Nomor 2, ISSN : 2086-0404

Budiardjo, Miriam. 2008. Dasar-dasar Ilmu Politik, Jakarta :Gramedia

Budiarjo, Miriam. 1990. Hak Asasi Manusia dalam Dimensi Global, Jurnal Ilmu Politik, No.10

Crocker, L \& Algina, J. 1986. Introduction to Classical and Modern Test Theory. Holt, Rinehart and Winston Inc, New York.

Dodi Achmad. 2013. Demokrasi Lokal - Evaluasi Pemilukada di Indonesia, Jakarta: Konpress

Hamid dan Lutfi,J. 2010. Civic Education antara Realitas Politik dan Implementasi Hukum. Jakarta: Gramedia

Huntington., Samuel., dan Joan Nelson, 1990. Partisipasi Politik di Negara Berkembang, Jakarta: Rineka Cipta 
Juanda. 2014. Pengaruh pembelajaran Pkn sebagai Pendidikan Politik terhadap prilaku memilih Pemilih Pemula (Kabupaten Aceh Timur). Jurnal CIVICUs, Volume 18, Nomor 1.Bandung:Universitas Pendidikan Indonesia

Junaidi.2013. Pendidikan Kewarganegaraan,Yogyakarta;Graha Ilmu.

Kristiadi,J. 1996. Pemilihan Umum dan Perilaku Pemilih di Indonesia, Prisma.No.3/1996. Jakarta :LP3ES.

Kusnardi.M., dan Harmaily Ibrahim, 1983. Pengantar Hukum Tata Negara Indonesia, Pusat Studi Hukum Tata Negara FHUI, Jakarta

Lasut, Vivaldi E.C. Partisipasi Politik Pemilih Pemula Pada Pemilihan Umum Legislatif 2014 Di Kecamatan Tomohan Utara, Jurnal.

Lion,Eddy. 2014. Pengaruh Pendidikan Kewarganegaraan (PKn) Terhadap Sikap Demokrasi Siswa SMA Negeri Se Kota Palangka Raya (Survey Terhadap Siswa Kelas XI SMA Negeri di Kota Palangka Raya), Jurnal Volume 2 Nomor 2, ISSN - 0236, Universitas Palangka Raya.

Mardapi, D. 2008. Teknik Penyusunan Instrumen Tes dan Non Tes. Mitra Cendekia Press. Yogyakarta.

Martini Eneng,dkk. 2018. Pengaruh Pendidikan Politik terhadap kesadaran partisipasi Pemilih Pemula di SMK PGRI 1 Cimahi Jawa Barat, Jurnal Volume 2, Nomor 1, ISSN 2337-8891, IKIP PGRI Pontianak.

Nasution,Fera,Hariani. 2009. Perilaku Pemilih Pada pemilihan Gubernur Sumatera Utara secara langsung di Kabupaten Labuhan Batu, Skripsi, Universitas Sumatera Utara Repository.

Nohe, Darnah A, dkk. 2013. Analisis Korelasi Somers'D Pada Tingkat Kenyamanan Siswa-Siswi SMP Plus Melati Samarinda. Jurnal Barekeng Vol.7 No.2. Hal 31-40

Rahmat,Dwi,Apriliani. 2014, Orientasi Politik Pemilih Pemula dalam Pemilihan Legislatif Tahun 2014, Jurnal PPKN UNJ Online- Volume 2 Nomor 4 Tahun 2014, ISSN : 2337 - 5205 : Universitas Negeri Jakarta

Renciansyah. 2015, Perilaku Pemilih Pemula Dalam Pemilihan Umum (Studi Kasus Pemilih Pemula di Kabupaten Siantan Tengah Kabupaten Anambas Tahun 2014), Naskah Publikasi, Universitas Maritim Raja Ali Haji.

Tutu,Chitra,Adelfien. 2010, Partisipasi Politik masyarakat dama Pemilihan Umum Kepala Daerah di Kabupaten Minahasa Selatan Tahun 2010 (Study di Kecamatan Amurung Timur Kabupaten Minahasa Selatan), Skripsi,

Triana,Rita,Budiarti (Editor). 2013, Himpunan Peraturan Perundangundangan Bidang Pemilu, Jakarta : Konstitusi Press

Ubaedillah A., dan Rozak Abdul. 2016. Pendidikan Kewarganegaraan (Civic Education) : Demokrasi, Hak Asasi Manusia dan Masyarakat Madani. ICCE UIN, Jakarta

Undang-Undang Republik Indonesia Nomor 7 Tahun 2017 tentang Pemilihan Umum;

Undang-Undang Republik Indonesia Nomor 39 Tahun 1999 tentang Hak Asasi Manusia 